\title{
Molecular Phylogeny of Sarawak Green Sea Turtle (Chelonia mydas) inferred by the D-loop region and $16 \mathrm{~S}$ rRNA gene.
}

\author{
NURHARTINI KAMALIA YAHYA, RUHANA HASSAN, \& AWANG AHMAD SALLEHIN \\ AWANG HUSAINI \\ Faculty of Resource Science and Technology \\ Universiti Malaysia Sarawak, Kota Samarahan, 94300 Sarawak, Malaysia.
}

\begin{abstract}
This study aimed to sequence the D-loop region and 16S rRNA gene of Chelonia mydas in order to determine the relationships between 15 individuals of green sea turtles nesting in two separate islands of Sarawak, namely the Satang Besar Island and the Talang-Talang Island. A total of 15 D-loop region sequences of $360 \mathrm{bp}$ and nine 16S rRNA gene sequences of $550 \mathrm{bp}$ were obtained in this study. Results based on these two genes showed that there are some genetic variations between samples collected from both islands. Pairwise distance analysis revealed between zero to $6 \%$ genetic divergence using information on D-loop region and zero to $1.8 \%$ genetic divergence using $16 \mathrm{~S}$ rRNA gene between individuals. The phylogenetic trees constructed using D-loop information revealed the presence of two clades in which clade A comprises of mixtures of individuals from both islands whereas clade B only showed individuals from Talang-Talang Island. Analysis of the 16S rRNA gene data set, only one clade was observed. More samples is needed in the future to clarify whether natal homing, chanceencounter or social facilitation hypothesis is more suited to Sarawak green turtle rookeries.
\end{abstract}

Keywords: Chelonia mydas, D-loop, 16S rRNA, Satang Besar Island, Talang-Talang Island, Sarawak Green Sea Turtle

\section{INTRODUCTION}

A fundamental and challenging research priority in conservation biology is to investigate the dispersal of endangered organisms (Naro-Maciel et al. 2006). Like other long-life span marine organisms, sea turtles are difficult to study during their marine life stages as their population structure and distribution are not fully understood (Formia et al. 2006). Sea turtles rank among the better known marine creatures in Malaysia, with a conservation history dating back to the 1950's. Four species of sea turtles, namely leatherback turtle (Dermochelys coriacea), green turtle (Chelonia mydas), hawksbill turtle (Eretmochelys imbricata) and olive ridley turtle (Lepidochelys olivacea) are found in Malaysia (Chan 2006). In Sarawak, the main green sea turtle nesting sites are concentrated on the Sarawak Turtle Islands of the Talang-Talang Besar, the Talang-Talang Kecil and the Satang Besar where populations from all the nesting sites have shown declining trends in terms of number of turtle landings, eggs collected and eggs hatched (Sarawak Forestry Department 1996). Over the last 141 years, the green sea turtle populations are estimated to have declined by 37-61\% and this have

*Corresponding author: nhkamalia@gmail.com resulted in the classification of the species as globally endangered (Seminoff 2004). One of the major factors that have contributed to the decline of the species in Malaysia are continued egg harvest for many decades and loss of nesting habitats due to coastal development for tourism (Chan 2006).

The earliest tagging programs in Malaysia were reported in 1953 on the green sea turtle population of Sarawak, where the tagging experiments have provided researchers with comprehensive biological information such as migration, growth, mortality and reproduction (Zulkifli et al. 2003). However, the inefficiency of tagging technology mostly by the loss of the tags due to poor tagging and corrosion (Mrosovsky 1976) had caused difficulties in the tracking process of the green sea turtle.

In many cases, mtDNA studies have delineated the structure of populations, and thus have provided reference for the level at which management priorities should be set for the protection of a particular species (Kaska 2000). Conservation efforts to reverse nesting declines and improving the population size at places such as Tortuguero, Costa Rica (Troeng et al. 2005) and Michoacan, Mexico using $400 \mathrm{bp}$ mtDNA control region sequences (Chassin-Noria et al. 2004) have been actively 
carried out to evade genetic erosion. Mitochondrial DNA data was used for the study related to turtles because it is maternally transmitted thus providing perspectives on female reproductive behavior that are paramount to species survival (Bowen \& Avise 1995).

The objective of this study is to sequence the Dloop and 16S rRNA genes of the green sea turtles obtained from Talang- Satang National Park. Up to date, there has been no molecular data of Chelonia mydas from Sarawak. This paper thus describes the preliminary findings on the phylogenetic grouping of Chelonia mydas obtained from Talang-Satang National Park based on D-loop and 16S rRNA sequences.

\section{MATERIALS \& METHODS}

Samples of $C$. mydas from the Talang-Talang Island and the Satang Besar Island (Figure 1) were donated by Sarawak Turtle Board (Sarawak Museum) to the previous researcher, Amirul Azwan bin Ainie (Permit Number: NPW.907.4.2(II)-92). All samples were kept in $-80^{\circ} \mathrm{C}$ in the Sanyo Ultra Low freezer. Total genomic DNA was isolated using modified version of CTAB protocol (Doyle \& Doyle 1987).

Amplification of the $360 \mathrm{bp}$ D-loop region were accomplished using Polymerase Chain Reaction (PCR) condition of $25 \mu \mathrm{l}$ of total reaction volume containing 100 to $110 \mathrm{ng}$ of turtle genomic DNA, 5 U/ $\mu$ l Taq DNA polymerase, 5 X PCR buffer, 25 $\mathrm{mM} \mathrm{MgCl}_{2}, 10 \mathrm{mM}$ of deoxynucleotide triphosphate (dNTP mix,) and $0.2 \mu \mathrm{M}$ of primers TCR-5 (5'-TTG TAC ATC TAC TTA TTT ACC AC-3') and TCR-6 (5'-GTA AGT AAA ACT ACC GTA TGC CAG GTT A-3') which were both designed by Norman et al. (1994). The reaction was carried out under the following conditions: 2 minutes at $94^{\circ} \mathrm{C}, 30$ cycles of 30 seconds at $94^{\circ} \mathrm{C}, 35$ seconds at $55^{\circ} \mathrm{C}$ and 30 seconds at $72^{\circ} \mathrm{C}$ followed by 2 minutes of $72^{\circ} \mathrm{C}$ using BIOER “Little Genius” PCR machine.

The PCR reaction used for amplification of $550 \mathrm{bp}$ of 16S rRNA gene was the same as D-loop except for the primers 16SAR (5'-CGC CTG TTT ATC AAA AAC AT-3') as the forward primer and 16SBR (5'-CCG GTC TGA ACT CAG ATC ACG T-3') as the reverse (Palumbi 1996). The reaction was carried out under the following condition: 2 minutes at $94^{\circ} \mathrm{C}, 30$ cycles of 30 seconds at $94^{\circ} \mathrm{C}, 35$ seconds at $50^{\circ} \mathrm{C}$ and 30 seconds at $72^{\circ} \mathrm{C}$ followed by 2 minutes of $72^{\circ} \mathrm{C}$. The fragments obtained were then visualised using $1 \%$ agarose gel electrophoresis premixed with ethidium bromide in $1 \mathrm{X}$ TAE buffer. The PCR products were then purified using Promega PCR Clean-Up System according to manufacturer's protocol and later sent for sequencing.

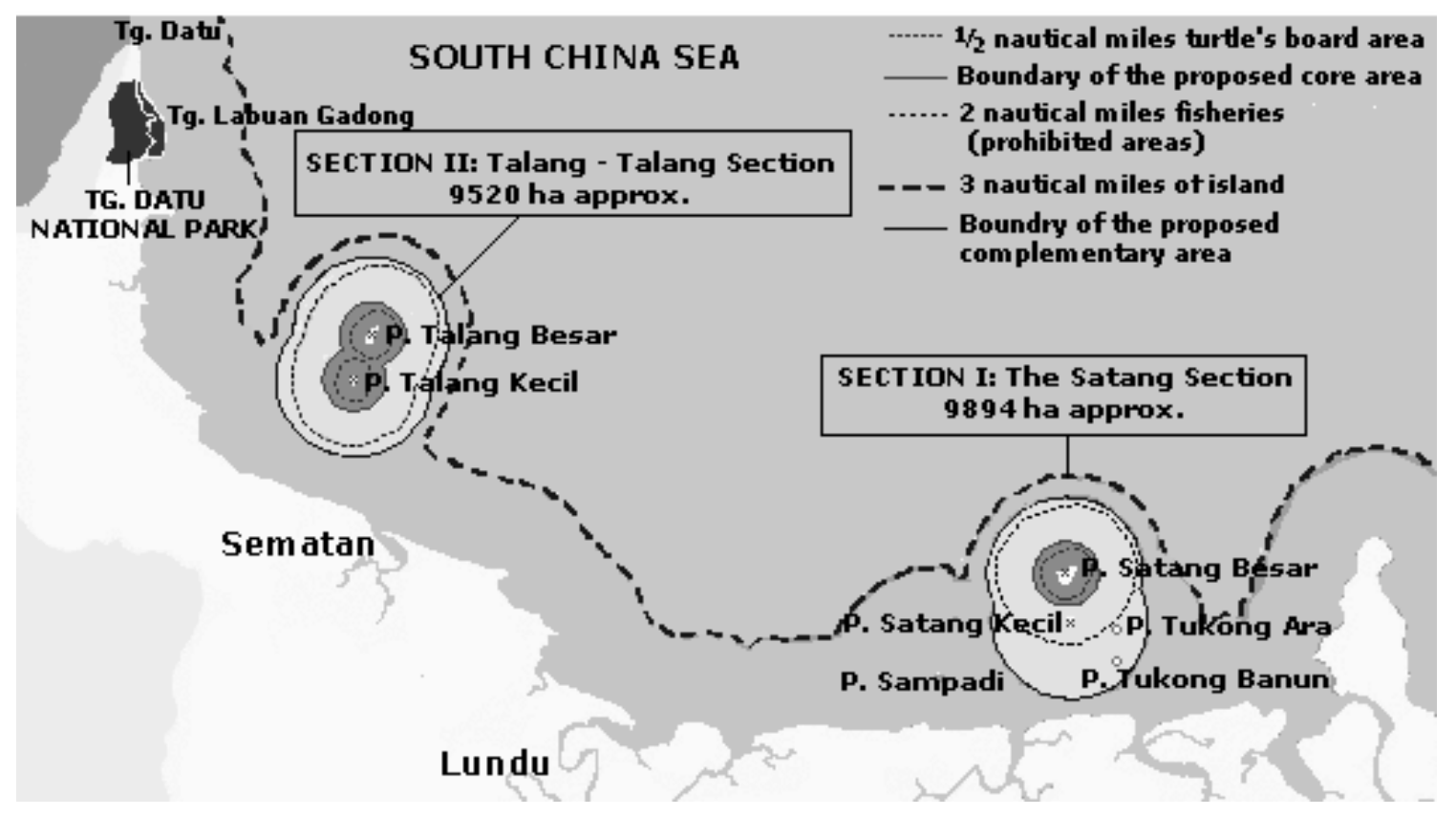

Figure 1. Map showing Talang-Satang National Park where samples of Chelonia mydas were obtained. Map adapted from Sea Turtle Adoption Program Handbook http://www.sarawakforestry.com/seaturtle / Turtle_ Handbook.pdf). 
The sequences were then subjected to automatic sequence alignment using Clustal $\mathrm{X}$ version 1.81 (Thompson et al. 1997). Transition and transversion percentage were observed and calculated manually as done by Khan et al. (2008). Then, the sequence data were subjected to two different methods of phylogenetic reconstructions: (i) unweighted pair group method with arithmetic mean (UPGMA) tree which was constructed using the MEGA 4.0 (Tamura et al. 2007) and (ii) Bayesian tree which was constructed using MrBayes (Huelsenbeck \& Ronquist 2001) for both genes. The Bayesian trees were constructed using likelihood settings from bestfit model selected by Akaike Information Criterion (AIC) and Hierarchical Likelihood Ratio Tests (hLRTs) in Modeltest 3.7 (Posada 2008). Supports of nodes for both UPGMA trees were assessed with bootstrap confidence level using 1000 replicates.

Pairwise genetic distance was also calculated based on Kimura's 2 Parameter model (Kimura 1980) using MEGA 4.0. All the partial D-loop and 16S rRNA sequences obtained in this study were then deposited into the GenBank. The GenBank accession numbers of the partial D-loop sequences deposited are HQ377528 - HQ377542 while the GenBank accession numbers for 16S rRNA deposited are HQ377543 - HQ377551. Further details regarding the GenBank accession number is as given in Table 1 . The outgroup sequences used in this study namely Dermochelys coriacea were also obtained from the GenBank with the accession number of AF121964 and FJ039907.

\section{RESULTS \& CONCLUSION}

Multiple sequence alignment of 15 sequences from the D-loop region after removal of stop codons revealed 29 observed variable sites including six insertions/deletions (indels) that were required at various sites whereas the nine 16S rRNA sequences alignment showed the presence of eleven variable sites, where one indel was required for the alignment. The average frequencies of identical (conserved) sequences were $98.56 \%$ for D-loop gene and $99.78 \%$ for $16 \mathrm{~S}$ rRNA gene (Figure 2). Transition also occurred at the rate of $1.33 \%$ for Dloop compared to $0.04 \%$ for $16 \mathrm{~S}$ rRNA gene (Figure 2). However, transversion which occurred at

Table 1. Samples of Chelonia mydas analyzed for DNA sequence variation with locality, label used for sequences in this study and GenBank accession number.

\begin{tabular}{|c|c|c|c|}
\hline Gene & Locality & Label & GenBank accession no. \\
\hline \multirow[t]{2}{*}{ D-loop } & $\begin{array}{c}\text { Talang-Talang } \\
\text { Island }\end{array}$ & $\begin{array}{c}\text { Talang } 1 \\
\text { Talang } 2 \\
\text { Talang } 3 \\
\text { Talang } 4 \\
\text { Talang } 5 \\
\text { Talang } 6 \\
\text { Talang } 7 \\
\text { Talang } 8 \\
\text { Talang } 9 \\
\text { Talang } 10\end{array}$ & $\begin{array}{l}\text { HQ377528 } \\
\text { HQ377529 } \\
\text { HQ377530 } \\
\text { HQ377531 } \\
\text { HQ377532 } \\
\text { HQ377533 } \\
\text { HQ377534 } \\
\text { HQ377535 } \\
\text { HQ377536 } \\
\text { HQ377537 }\end{array}$ \\
\hline & $\begin{array}{l}\text { Satang Besar } \\
\text { Island }\end{array}$ & $\begin{array}{l}\text { Satang } 1 \\
\text { Satang } 2 \\
\text { Satang } 3 \\
\text { Satang } 4 \\
\text { Satang } 5 \\
\end{array}$ & $\begin{array}{l}\text { HQ377538 } \\
\text { HQ377539 } \\
\text { HQ377540 } \\
\text { HQ377541 } \\
\text { HQ377542 }\end{array}$ \\
\hline \multirow[t]{2}{*}{ 16S rRNA } & $\begin{array}{c}\text { Talang-Talang } \\
\text { Island }\end{array}$ & $\begin{array}{l}\text { Talang } 1 \\
\text { Talang } 2 \\
\text { Talang } 3 \\
\text { Talang } 4 \\
\text { Talang } 5\end{array}$ & $\begin{array}{l}\text { HQ377543 } \\
\text { HQ377544 } \\
\text { HQ377545 } \\
\text { HQ377546 } \\
\text { HQ377547 }\end{array}$ \\
\hline & $\begin{array}{l}\text { Satang Besar } \\
\text { Island }\end{array}$ & $\begin{array}{l}\text { Satang } 1 \\
\text { Satang } 2 \\
\text { Satang } 3 \\
\text { Satang } 4 \\
\end{array}$ & $\begin{array}{l}\text { HQ377548 } \\
\text { HQ377549 } \\
\text { HQ377550 } \\
\text { HQ377551 }\end{array}$ \\
\hline
\end{tabular}




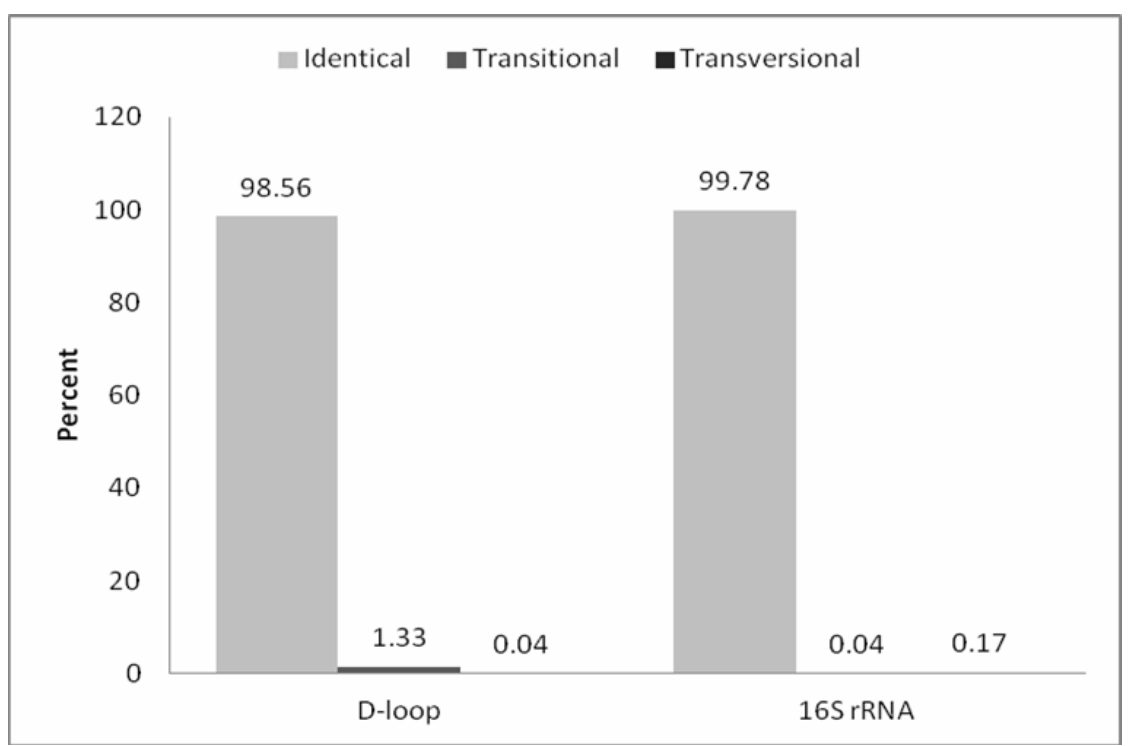

Figure 2. Average frequencies of identical (conserved) and substituted (transitional and transversional) sites observed in sequence comparison for the D-loop region and 16S rRNA gene obtained from individuals of $C$. mydas from Talang-Talang and Satang Besar Islands.

$0.04 \%$ for D-loop was less than $16 \mathrm{~S}$ rRNA rate of $0.17 \%$ (Figure 2). The D-loop region's condition of higher transition rate when compared to transversion supports the fact that transitions occur more often than transversions in the evolution of real sequences (Khan et al. 2008).

Bradley and Baker's (2001) theory of genetic distance values under the framework of Genetic Species Concept was used as the reference point for species level differentiation for C. mydas. Accordingly, the distance value of less than $2 \%$ indicates intraspecific variation while values between 2 and $11 \%$ shows that there is a need for additional study concerning specific status of a species while the value of more than $11 \%$ indicates specific recognition. With reference to Table 2 for the pairwise distance of $C$. mydas based on D-loop gene, the lowest pairwise distance observed was $0 \%$ where no differences were observed between $C$. mydas Talang sample 1, 2 and 10 and also C. mydas Satang sample 4, 5, 3, 2, 1 and also in Talang sample 9, 7, 6 and 3 which shows that these samples are interpopulational. This could have been caused by the individuals sampled originating from the same maternal lineage or the same clutch. The highest pairwise distance value obtained was 6.0\% between $C$. mydas Talang sample 8 and Satang sample 4,5,3,2,1 and also Talang sample 9,7,6,3, and 5 where the value indicates that the variation was still within a species level but could either be an intrasubspecific or intraspecific variation.
For the genetic distance of sequences based on 16S rRNA gene (Table 3), there is no difference in terms of genetic distance was observed between $C$. mydas Talang 2 and $C$. mydas Talang 3 and 5 and also C. mydas Satang 1, 2 and 4. Meanwhile, the highest distance value was $1.8 \%$ which was between C. mydas Satang 3 and C. mydas Talang 1 which still indicates that the samples are interpopulational.

Detailed analysis of the topology of the D-loop UPGMA phylogenetic tree (Figure 3) showed two clades (clade A and clade B). The overall bootstrap support was strong (99\% for clade A and and 98\% for clade B) thus producing a robust tree topology which was further supported by the topology of the Bayesian D-loop tree (Figure 4). Clade A consists of C. mydas from both Talang-Talang and Satang Besar Island while clade B consists of samples only from Talang-Talang Island (sample 1, 2, 8 and 10). Clade B comprises of only Talang-Talang samples because the individuals sampled could have been from the same clutch or the same maternal lineage. This finding is supported by the green turtle's habit of nesting colonially or in many locations as the females utilize specific beaches (Bowen et al. 1992). In addition, Bowen et al. (1992) also stated that nestmates are normally expected to be identical in mtDNA genotype. The mixture of individuals from Talang-Talang and Satang Besar Island in Clade A could be explained by several possibilities namely, 
location-wise, landscape similarity and also the behaviour of the sea turtles themselves. Behaviourwise, Clade A and B could have been the result of natal homing and social facilitation. Based on the postulate put forward by Carr (1967), the female turtles that might have originated from one of the island could have returned to its natal nesting beach to reproduce where if females were to return faithfully to their rookery of origin, then each nesting population should possess a unique genetic signature in terms of female transmitted mtDNA (Bowen \& Karl 2007). This can be observed through clade B where the individuals samples could be from the same or closely related maternal line. As for clade A, the presence of Satang Besar samples in the midst of Talang-Talang samples could have been due to social facilitation as the first time nesting females that might have originated from Talang-Talang Island follow experienced breeders from the feeding habitat to a nesting beach and use this site for all subsequent nesting (Hendrickson 1958).

Alternatively, the chance-encounter theory could also be applied in this matter as it is possible for first time breeders to randomly encounter a suitable nesting beach and use it for subsequent nesting (Carr 1986). In addition, location between the two islands is only approximately 4 kilometers apart, a distance which is considered near for the sea turtles. Furthermore, the condition of both the islands in which both had similar landscape with limited sandy beaches might have caused the mixture in clade A since C. mydas from Satang Besar or Talang-Talang Island could have mixed its nesting site by nesting at both islands instead of only one since there is not much difference between the islands. Bowen et al. (1992) have also said that even if natal homing predominates, migrational "mistakes" must have occurred to account for the widespread distribution of rookeries worldwide.

Climatic fluctuations, which could have also altered the availability of green turtle habitats promotes strays and wandering, which are both advantageous and adaptable change necessary for colony proliferation (Carr et al. 1978).

Only nine $16 \mathrm{~S}$ rRNA gene sequences were used for the construction of the UPGMA phylogenetic tree (Figure 5), high bootstrap (Felsenstein 1985) value $(95 \%)$ shows that the branches support the population or subpopulation structure of $C$. mydas. Based on the tree obtained, it shows that all other sequences belonged to the same clade except for $C$. mydas Talang 1.

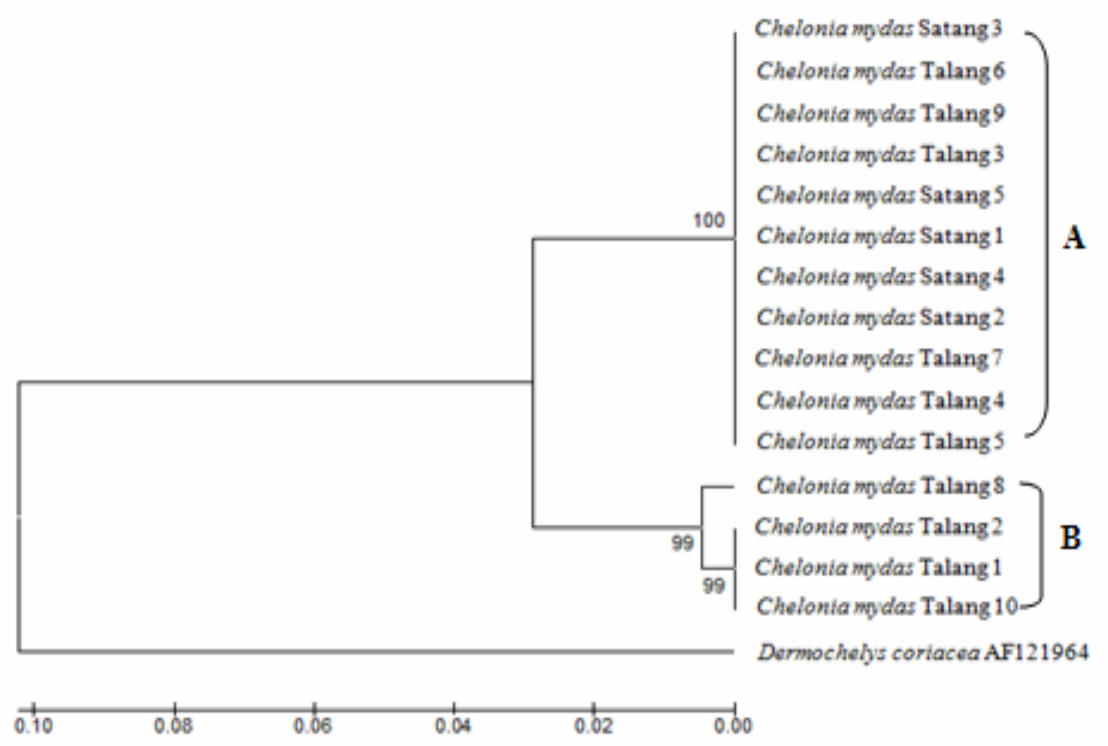

Figure 3. UPGMA tree constructed using Kimura 2 parameter genetic distances for D-loop gene of $C$. mydas from Talang-Talang and Satang Besar Islands. 


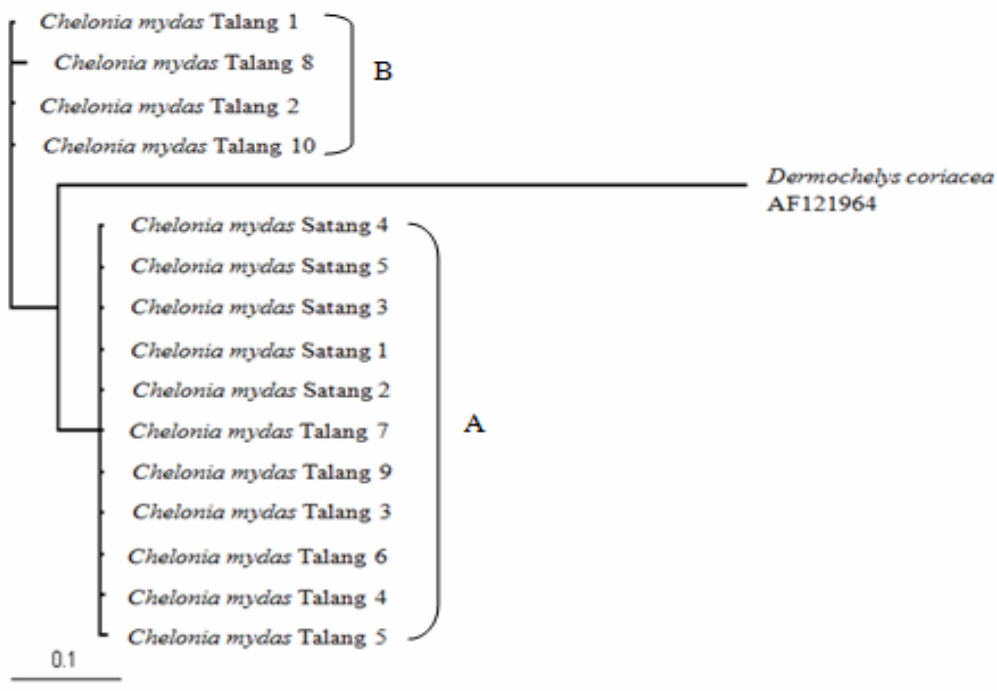

Figure 4. Bayesian D-loop gene tree constructed using likelihood settings from best-fit model (HKY) selected by Hierarchical Likelihood Ratio Tests (hLRTs) in Modeltest 3.7.
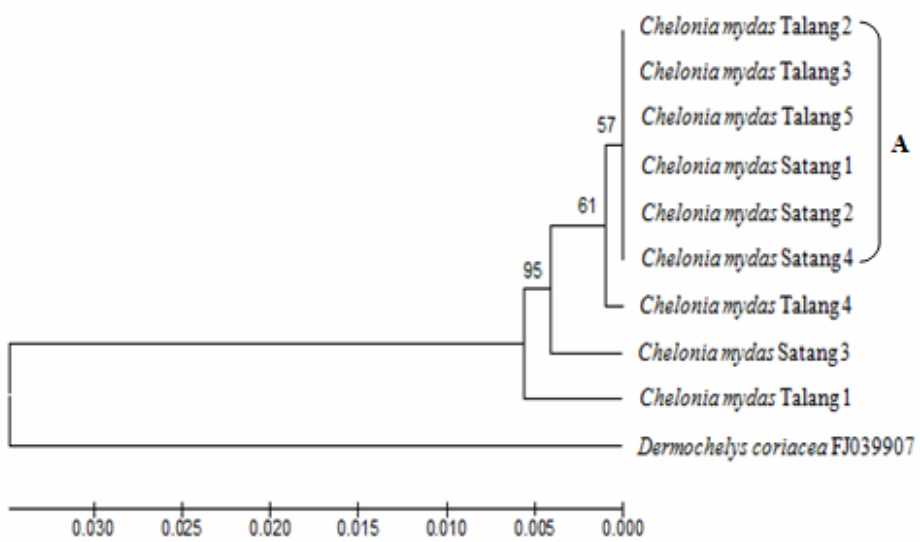

Figure 5. UPGMA tree constructed using Kimura 2 parameter genetic distances for $16 \mathrm{~S}$ rRNA gene of C. mydas from Talang-Talang and Satang Besar Islands.

The theory of natal homing, social facilitation, distance, climate change and geographical similarity as discussed for D-loop region is also applicable for this gene. The separation of $C$. mydas Talang 1 from clade A could have been caused by the individual sampled originating from a different maternal lineage or origin. This is further supported by the Bayesian tree (Figure 6) which shows ancestral lineage in which Talang 1 shows definite difference in terms of branch length.

If $C$. mydas Talang 1 is from a different origin that ended up in Talang-Talang Island due to social facilitation factor, it would take some time for the individual to be able to achieve a reciprocal mono- phyletic state (Bowen et al. 1992). However, this situation also merits further research in future. Most likely, the 16S rRNA gene is not very suitable for inferring phylogenies. Moreover, the small sample size might have also affected the overall results, as size of 20 samples is recommended for most population assessment (FitzSimmons et al. 1999).

This study only involved fifteen C. mydas samples. It should be noted that the sample limitation was actually due to the endangered status of this species thus making it very hard to obtain more samples. For future study, more samples from different geographical areas in Sarawak as well as other parts of Malaysia should be included in the 


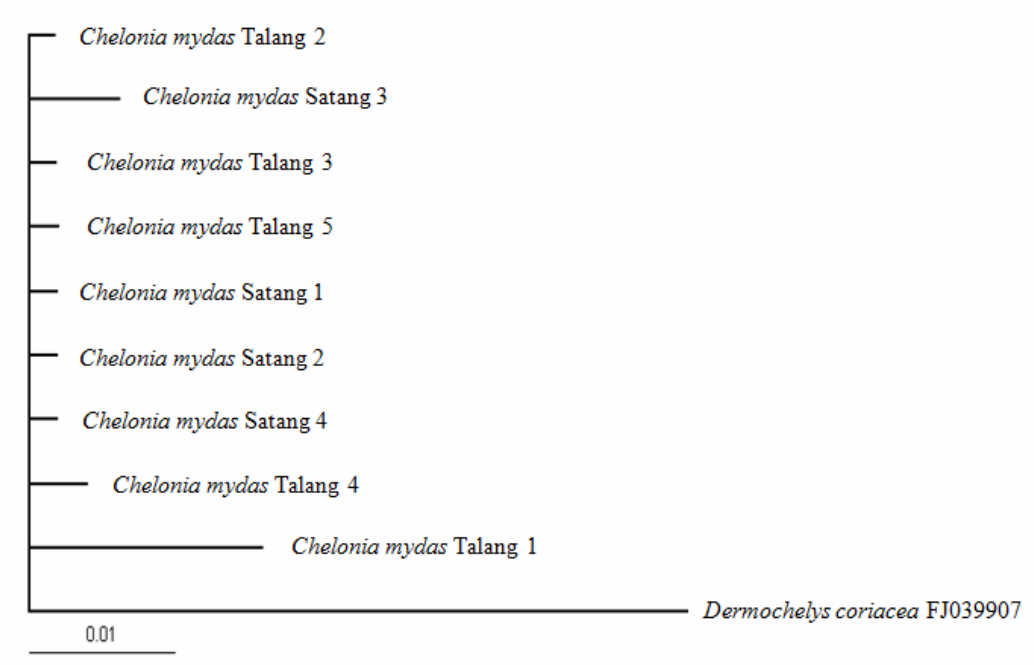

Figure 6. Bayesian 16S rRNA gene tree constructed using likelihood settings from best-fit model (TrN) selected by Akaike Information Criterion (AIC) in Modeltest 3.7.

analysis to further understand the migration pattern of the green sea turtle in Malaysia. In addition, future research should also explore sequencing other genes for example cytochrome b (cyt $b$ ) gene and nuclear genes to understand evolutionary patterns within Testudines.

\section{ACKNOWLEDGEMENT}

This project was carried out using fund from Belanjawan Mengurus Fakulti, University Malaysia Sarawak (UNIMAS). Thank you to Sarawak Turtle Board for samples donation, and to Sarawak Forestry Department for the permit to collect samples. Special acknowledgment also goes to the staff and students of Aquatic Molecular Biology Laboratory, Faculty of Resource Science and Technology, UNIMAS for technical assistance and moral support given throughout this project.

\section{REFERENCES}

Bradley, R.D. \& Baker, R.J. (2001). A Test of the Genetic Species Concept: Cytochrome-b Sequences and Mammals. Journal of Mammalogy, 82(4): 960-973.

Bowen, B.W. \& Avise, J.C. (1995). Conservation genetics of marine turtles. In J.C. Avise and J.L. Hamrick, Conservation Genetics: Case Histories from Nature. New York: Chapman and Hall.

Bowen, B.W. \& Karl, S.A. (2007). Population genetics and phylogeography of sea turtles. Molecular Ecology, 16, 4886-4907.
Bowen, B.W., Meylan, A.B., Ross, J.P., Limpus, C.J., Balasz, G.H. \& Avise, J.C. (1992). Global population structure and natural history of the green turtle (Chelonia mydas) in terms of matriarchal phylogeny. Evolution, 46(4): 865881.

Carr, A. (1967). So Excellent a Fisher: A Natural History of Sea Turtles. Scribner, New York.

Carr, A., Carr, M.H. \& Meylan, A.B. (1978). The Ecology and Migration Of Sea Turtles,7. The West Carribean Green Turtle Colony. Bulletin of the American Museum of Natural History, 162: 1-46.

Carr, A. (1986). Rips, FADS, and little loggerheads. BioScience, 36(2): 92-100.

Chan, E.H. (2006). Marine turtles in Malaysia: On the verge of extinction? Aquatic Ecosystem Health and Management, 9: 175-184.

Chassin-Noria, O., Abreu-Grobois, A., Dutton, P.H. \& Oyama, K. (2004). Conservation genetics of the east Pacific green turtle (Chelonia mydas) in Michoacan, Mexico. Genetica, 121: 195-206.

Doyle, J. J., and J. L. Doyle. (1987). A Rapid DNA Isolation Procedure for Small Quantities of Fresh Tissue. Phytochemistry Bulletin 19: 11-15.

Felsenstein, J. (1985). Confidence limits on phylogenies : An approach using the bootstrap. Evolution, 39: 783-791. 
Formia, A., Godley, B.J., Dontaine, J.F. \& Bruford, M.W. (2006). Mitochondrial DNA diversity and phylogeography of endangered green turtle (Chelonia mydas) populations in Africa. Conservation Genetics, 7:353-369.

Hendrickson, J.R. (1958). The green sea turtle, Chelonia mydas (Linn.) in Malaya and Sarawak. Proceedings of the Zoological Society of London, 130: 455-535.

Hillis, D.M., Moritz, C. \& Mable, B.K. (1996). Molecular Systematics, Second Edition. U.S.A.: Sinauer Associates Inc.

Huelsenbeck, J.P. \& Ronquist, F.R.. (2001). MrBayes: Bayesian inference of phylogenetic trees. Bioinformatics, 17:754-755.

Kaska, Y. (2000). Genetic Structure of Mediterranean Sea Turtle Populations. Turkish Journal of Zoology, 24: 191-197.

Khan, H.A., Arif, I.A., Bahkali, A.H., Al Farhan, A.H. \& Al Homaidan, A.A. (2008). Bayesian, Maximum Parsimony and UPGMA Models for Inferring the Phylogenies of Antelopes using Mitochondrial Markers. Evolutionary Bioinformatics, 4:263-270.

Kimura, M. (1980). Kimura's two-parameter model of Models of DNA Evolution. In: Felsenstein, J. (2004). Inferring Phylogenies. Sunderland, Massachusetts: Sinauer Associates, Inc.

Mrosovsky, N. (1976). IUCN/SSC: Marine Turtle Newsletter. No.1. August 1976.

Naro-Maciel, E., Becker, J.H., Lima, E.H.S.M., Marcovaldi, M.A. \& DeSalle, R. (2006). Testing dispersal hypotheses in foraging green sea turtles (Chelonia mydas). Brazil Journal of Heredity.

Norman, J. A., Moritz,C. \& Limpus, C. J. (1994). Mitochondrial DNA control region polymorphisms: genetic markers for ecological studies of marine turtles. Molecular Ecology 3:363-373.
Page, R. D. M \& Holmes, E.C., (1998). Molecular Evolution: A Phylogenetic Approach (1st ed.). Blackwell Science Ltd..

Palumbi, S.R. (1996). Nucleic Acids II: the polymerase chain reaction. In: Hillis D.M., Moritz, C., Mable B.K., (Eds.), Molecular Systematics. Sunderland, Mass.: Sinauer, pp. 205247.

Posada, D. (2008). jModelTest: phylogenetic model averaging molecular biology and evolution. Molecular Biology Evolution, 25:1253-1256.

Sarawak Forestry Department and Wildlife Conservation Society (1996). A Master Plan For Wildlife in Sarawak.

Seminoff, J.A. (2004). Chelonia mydas. In: IUCN 2007. 2007 IUCN Red List of Threatened Species. http://www.iucnredlist.org/

Tamura, K., Dudley, J., Nei, M. \& Kumar, S., (2007). MEGA4: Molecular Evolutionary Genetics Analysis (MEGA) Software Version 4.0.

Thompson, J.D., Gibson, T.J., Plewniak, F., Jeanmougin, F. \& Higgins, D.G., (1997). The ClustalX Windows interface: flexible strategies for multiple sequence alignment aided by quality analysis tool. Nucleic Acids Research, 24: 48764882.

Troeng, S., Evans, D.R., Harrison, E \& Lagueux, C.J. (2005). Migration of green turtles Chelonia mydas from Tortuguero, Costa Rica. Marine Biology, 148: 435-447.

Zulkifli, T., Ahmad, A. \& Ku Kassim, K.Y. (2003). Managing Sea Turtles in Southeast Asia: Hatcheries and Tagging Activities. FISH for the PEOPLE. 1(3):27-33. 